\title{
Epstein-Barr Virus EBNA-2 Polymorphic Patterns in Nasopharyngeal Carcinoma in Southern China
}

\author{
Guocai Wuª Xia Liu ${ }^{a, b}$ Song Liu ${ }^{a}$ Jun Shu ${ }^{a}$ Zhifu Sun ${ }^{c}$ Bing Luo ${ }^{a}$ \\ ${ }^{a}$ Department of Medical Microbiology, Qingdao University Medical College, and ${ }^{b}$ The Affiliated Hospital of Qingdao \\ University, Qingdao, PR China; ' Department of Health Sciences Research, Mayo Clinic, Rochester, Minn., USA
}

\section{Key Words}

Epstein-Barr virus - Nasopharyngeal carcinoma - Nuclear antigen $2 \cdot$ Polymorphism

\begin{abstract}
Objectives: The aim of this study was to characterize the specific Epstein-Barr virus (EBV) polymorphisms from nasopharyngeal carcinoma (NPC) patients and healthy donors in Southern China, and to explore the relationship between EBV genotypes and NPC. Methods: The EBNA-2 gene of 32 EBV-positive NPCs and 39 EBV-positive throat washing (TW) samples from healthy individuals from Southern China was analyzed using PCR and sequencing. Results: We found E2-A to be the predominant subtype in Southern China. The distribution of EBNA-2 subtypes between NPCs and TWs was significantly different $(p<0.01)$ and the E2-A subtype was overly represented in NPCs. Conclusions: E2-A is the predominant subtype in Southern China, and the distribution of EBNA-2 subtypes between NPCs and TWs is significantly different. In Southern China, the E2-A subtype is significantly more frequent in NPCs than TWs, and is also more common than in Northern China. This suggests that the E2-A subtype may play an important role in the pathogenesis of NPC and that EBNA-2 gene variations are tumor-specific polymorphisms.

(c) 2016 S. Karger AG, Basel
\end{abstract}

\section{Introduction}

Epstein-Barr virus (EBV) is a human herpesvirus that infects over $90 \%$ of the human population and has been linked to numerous malignant/benign diseases, including Burkitt's lymphoma, posttransplant lymphoproliferative disorders, undifferentiated nasopharyngeal carcinoma (NPC), Hodgkin's lymphoma and infectious mononucleosis [1-3]. NPC is a squamous cell carcinoma of the head and neck that is closely associated with EBV infection, with a high prevalence in certain regions of Southern China [4-6]. The exact role of EBV in the pathogenesis of EBV-associated malignancies remains to be determined. The fact that EBV infection is ubiquitous around the world yet the incidence of EBV-associated malignancies differs geographically raises the possibility that certain EBV strains may contribute to the development of specific EBV-associated malignancies [7-11].

EBV nuclear antigen protein 2 (EBNA-2) is one of the first latent proteins detected after an EBV infection [12]. EBNA-2 primarily upregulates the expression of viral and cellular genes, including CD23, CD21, c-myc and the viral EBNA-C promoter [13-15]. EBNA-2 is also known to interact with other transcription factors involved in the Notch signaling pathway $[16,17]$. This pathway is important in cell fate determination in the fruit fly and

\section{KARGER 125}

(c) 2016 S. Karger AG, Base

0300-5526/16/0586-0386\$39.50/0

E-Mail karger@karger.com

www.karger.com/int
Bing Luo

Department of Medical Microbiology, Qingdao University Medical College 38 Dengzhou Road

Qingdao 266021 (PR China)

E-Mail qdluobing@163.com 
may play a role in the development of T-cell lymphoma in humans.

In our previous studies on EBNA-2 gene polymorphism in NPC and EBV-associated gastric carcinomas from Northern China, 4 variations (AA417, 470, 476 and 486) were detected only in NPC, raising the possibility that strains with specific variations may associate with the development of NPC [18]. Here, we aimed to elucidate the variations of the EBNA-2 gene and potential association of EBNA-2 with the development of NPC in Southern China, as well as the potential differences between Southern and Northern Chinese samples. To do this we further collected 32 NPC specimens and 39 throat washing (TW) samples from Southern Chinese healthy donors in order to sequence and characterize the sequence variation of EBNA-2, which we then compared with the previously analyzed variation patterns in the NPC samples from Northern China.

\section{Materials and Methods}

\section{Specimens and DNA Extraction}

Paraffin-embedded NPC tissues were collected from Guangzhou province in Southern China, which is an endemic NPC area. Infection with EBV in NPC tissues was determined by EBER-1 (EBV-encoded small RNA 1) in situ hybridization, as described previously [19]. The cases with EBER1-positive signals in carcinoma cells were classified as EBV-positive NPCs and the DNA was extracted using the QIAamp DNA FFPE tissue kit (Qiagen $\mathrm{GmbH}$, Hilden, Germany). TWs were collected from 135 age- and gendermatched healthy blood donors in the same geographic regions by gargling with $10 \mathrm{ml}$ of phosphate-buffered saline. DNA was extracted from TWs using standard methodology employing proteinase $\mathrm{K}$ digestion and phenol-chloroform purification. The EBV-positive TWs were determined by positive BamHI W fragment signals using PCR with a BamHI W-specific primer pair [20]. All extracted DNA was stored at $-20^{\circ} \mathrm{C}$. All the study subjects gave their informed consent for the study, which was approved by the Medical Ethics Committee at the Medical College of Qingdao University, China.

\section{Amplification of the EBNA-2 Gene}

Nested PCR was used to amplify the DNA sequence coding 331-487 aa of EBNA-2. The sequences used in this research were described in our previous study [18]. The first round of PCR was performed in a total volume of $25 \mu \mathrm{l}$ containing $1 \times$ PCR reaction buffer, $100 \mathrm{ng}$ of genomic DNA, $0.5 \mu \mathrm{M}$ of each primer, $200 \mu \mathrm{M}$ of each deoxyribonucleotide triphosphate, and 1 unit Pfu of Taq polymerase (TaKaRa Biotechnology Co. Ltd., Kyoto, Japan). PCR amplification was performed with an initial denaturation at $94^{\circ} \mathrm{C}$ for $5 \mathrm{~min}$. Then, 35 cycles were carried out with denaturation at $94^{\circ} \mathrm{C}$ for $30 \mathrm{~s}$, annealing at $53^{\circ} \mathrm{C}$ for $30 \mathrm{~s}$, with extension at $72^{\circ} \mathrm{C}$ for $1 \mathrm{~min}$. A final elongation step at $72^{\circ} \mathrm{C}$ for $10 \mathrm{~min}$ was also conducted. The products of the first round of PCR were amplified in the second round with the primers EBNA-2-N/E; identical condi- tions were used in both rounds. DNA from the EBV-positive B958 and EBV-negative Ramos cell lines were used as positive and negative controls, respectively. The PCR products were separated by electrophoresis through $1.5 \%$ agarose gel and photographed under a UV light transilluminator after the gels were stained with ethidium bromide.

\section{Sequencing Analysis of the PCR Products}

The PCR products were purified using a gel extraction kit (QIAEX II; Qiagen $\mathrm{GmbH}$ ) according to the directions of the manufacturer. For sequencing, the purified products were sent to Shanghai Mapbiotech Co. Ltd. Bidirectional sequencing was carried out to ensure that any variations were not due to experimental variability

\section{Data Analysis}

All sequences were aligned and categorized based on their consensus sequence. One sequence was chosen to represent samples with identical sequences. Alignments between representative sequences were performed using MegAlign in DNA Star software (DNASTAR Inc., version 5.0), and a phylogenetic tree was constructed using the Clustal W method.

The distribution differences of EBNA-2 subtypes between NPCs and TWs were compared and analyzed by Fisher's exact test. The variant subtype distributions between the NPC samples from Southern and Northern China were compared using Fisher's exact test. Differences were considered significant at $p<0.05$. SPSS 15.0 statistical software (SPSS, Chicago, Ill., USA) was used for the statistical analyses.

\section{Results}

\section{Sequence Variation Patterns of EBNA-2 in Southern} China

All of the samples (32 NPCs and 39 TWs) were successfully amplified and sequenced. A phylogenetic tree was created according to the representative unique sequences (fig. 1). Based on the variation patterns and our previous studies on EBNA-2, 3 subtypes were identified: E2-A, E2-C and B95-8-like (fig. 2) [18].

The most common subtype was E2-A (represented by NPC1). In this subtype, 5 common mutations were identified, including 2 missense mutations at residues 476 (Glu $\rightarrow$ Gly/Trp) and 486 (Ile $\rightarrow$ Thr), and 3 same-sense mutations at residues $370(\mathrm{cct} \rightarrow \mathrm{cca}), 417(\mathrm{acg} \rightarrow \mathrm{aca})$ and $470(\mathrm{tca} \rightarrow \mathrm{tct})$. Additional sporadic mutations were observed at 6 residues, 331 (Pro $\rightarrow \mathrm{Leu}), 383(\mathrm{cct} \rightarrow \mathrm{cca}), 390$ $($ ggt $\rightarrow$ gga), $411($ Val $\rightarrow$ Ile), 438 (Ile $\rightarrow$ Leu) and 484 (Pro $\rightarrow$ His).

The second most common subtype was E2-C (represented by NPC3). In this subtype there was 1 common mutation (AA370, cct $\rightarrow \mathrm{cca}$ ) and 2 AA deletions (AA357 and 358). Additional sporadic mutations were observed 
Fig. 1. Phylogenetic tree based on the comparison of EBNA-2 amino acid sequences of 13 representative isolates using the Clustal $\mathrm{W}$ method. The analyzed regions were 331-487 aa of the EBNA-2 gene.

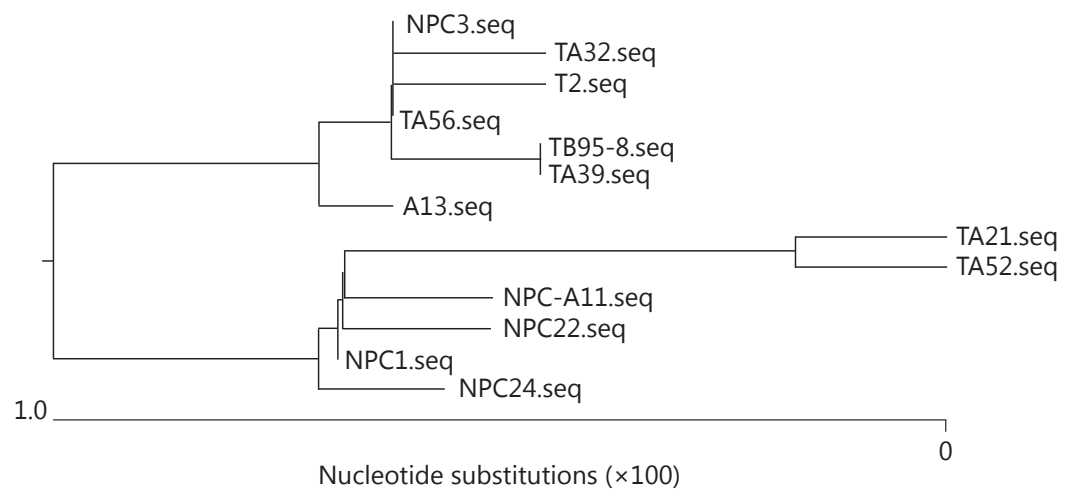

Nucleotide substitutions $(\times 100)$

\begin{tabular}{|c|c|c|c|c|c|c|c|c|c|c|c|c|c|c|c|c|}
\hline \multirow{3}{*}{ Subtype } & & \begin{tabular}{|l|}
331 \\
\end{tabular} & 357 & 358 & \begin{tabular}{|l|}
370 \\
\end{tabular} & 378 & \begin{tabular}{|c|}
383 \\
\end{tabular} & \begin{tabular}{|c|}
390 \\
\end{tabular} & 411 & 417 & \begin{tabular}{|l|}
438 \\
\end{tabular} & 451 & \begin{tabular}{|l|}
470 \\
\end{tabular} & \begin{tabular}{l|}
476 \\
\end{tabular} & 484 & $\overline{486}$ \\
\hline & & $\begin{array}{l}P \\
\mathbf{c} \\
\mathbf{c}\end{array}$ & $\begin{array}{c}\mathrm{K} \\
\text { a a } \mathrm{g} \\
\end{array}$ & $\begin{array}{c}\mathbf{G} \\
\mathrm{g} \mathrm{g} \mathrm{c}\end{array}$ & $\begin{array}{ccc} & P \\
c & c & t\end{array}$ & $\begin{array}{l}S \\
\text { t } \mathrm{c} c\end{array}$ & 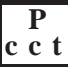 & \begin{tabular}{|c|}
$G$ \\
$g$ g t
\end{tabular} & $\begin{array}{l} \\
g \\
\end{array}$ & $\begin{array}{c}\mathrm{T} \\
\mathrm{a} \text { c } \mathrm{g}\end{array}$ & I t & $\begin{array}{l}P \\
\text { c c c }\end{array}$ & \begin{tabular}{ll|} 
& $S$ \\
$t$ & $c$
\end{tabular} & \begin{tabular}{|c|} 
E \\
g a
\end{tabular} & $\begin{array}{l}\mathbf{P} \\
\mathrm{c} \quad \mathrm{c}\end{array}$ & $\begin{array}{ll}\text { I } \\
\text { a t }\end{array}$ \\
\hline & China & 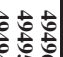 & & & & & & & & & & & 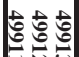 & t: & t: & t: \\
\hline \multirow{6}{*}{$\begin{array}{c}\text { E2-A } \\
(23 / 15)\end{array}$} & NPC1 (20/10) & & & & $\mathbf{a}$ & & & & & a & & & $\mathbf{t}$ & G & & $\begin{array}{l}\text { T } \\
\text { c }\end{array}$ \\
\hline & TA21 (0/1) & & & & a & & a & & & & $c^{\mathrm{L}}$ & & t & $\begin{array}{l}\text { G } \\
\text { g }\end{array}$ & $\begin{array}{l}\mathbf{H} \\
\mathbf{a}\end{array}$ & $\begin{array}{l}\text { T } \\
\text { c }\end{array}$ \\
\hline & TA52 (0/1) & & & & a & & & g & & & $c^{\mathrm{L}}$ & & $\mathbf{t}$ & $\begin{array}{l}\mathbf{G} \\
\mathrm{g}\end{array}$ & $\begin{array}{l}\mathbf{H} \\
\mathbf{a}\end{array}$ & $\begin{array}{l}\mathbf{T} \\
\mathbf{c}\end{array}$ \\
\hline & NPC22 (1/0) & & & & a & & & & & $\mathbf{a}$ & & & t & $\begin{array}{l}\mathrm{W} \\
\mathrm{tg}\end{array}$ & & $\begin{array}{l}\mathrm{T} \\
\mathrm{c}\end{array}$ \\
\hline & NPC24 (1/1) & & & & a & & & & $\mathbf{a}$ & a & & & t & G & & $\begin{array}{l}\mathrm{T} \\
\mathrm{c}\end{array}$ \\
\hline & NPC-A11 (1/2) & $\begin{array}{l}\mathrm{L} \\
\mathrm{t}\end{array}$ & & & a & & & & & a & & & $\mathrm{t}$ & $\begin{array}{l}\mathbf{G} \\
\mathbf{g}\end{array}$ & & $\begin{array}{l}\text { T } \\
\text { c }\end{array}$ \\
\hline \multirow{4}{*}{$\begin{array}{l}\text { E2-C } \\
(9 / 14)\end{array}$} & NPC3 (8/11) & & * & * & a & & & & & & & & & & & \\
\hline & T2 (0/1) & & $*$ & * & & $\mathbf{Y}$ & & & & & & & & & & \\
\hline & TA32 (0/2) & & $*$ & $*$ & a & & & & & & & $\begin{array}{l}\mathbf{H} \\
\mathbf{a}\end{array}$ & & & & \\
\hline & NPC-A13 (1/0) & & $*$ & $*$ & a & & & & $\mathbf{a}$ & & & & & & & \\
\hline \multirow{2}{*}{$\begin{array}{c}\text { B95-8- } \\
\text { like (0/10) }\end{array}$} & T39 (0/2) & & & & & & & & & & & & & & & \\
\hline & TA56 (0/8) & & & & a & & & & & & & & & & & \\
\hline
\end{tabular}

Fig. 2. EBNA-2 sequence variations in NPCs and TWs of healthy donors in Southern China. The numbers across the top correspond to the amino acid positions under which the B95-8 prototype amino acid and nucleotide sequence are listed. Different patterns are indicated in the left column while the specimens showing sequences identical to each other are represented by a single isolate in the second column. The numbers in parentheses indicate the number of identical sequences from NPCs and TWs, respectively. Only sequences that differed from B95-8 are indicated. For example,
NPC1 (20/10) indicates that 20 NPCs and 10 TWs had an identical sequence, and we chose NPC1 as the representative isolate. The lowercase letters indicate the nucleotide, and the amino acids are represented by capital letters. The consensus mutations of each pattern are shaded. Asterisks $\left(^{*}\right)$ indicate the deletion of an amino acid. T and TA represent the TW samples, and NPC and NPC-A represents the NPC tissues. A 6-bp insertion of gcaagg between nucleotide 49566 and 49567 was identified in TA21. 


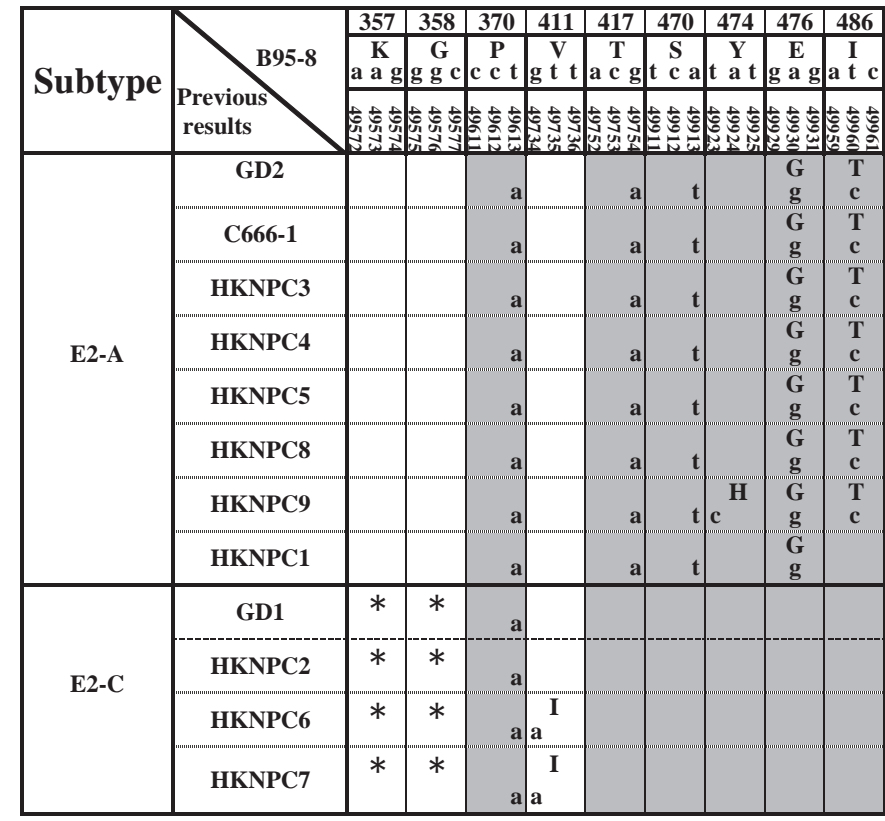

Fig. 3. Results from the study by Kwok et al. [21] and other previously published NPC strains. The numbers across the top correspond to the amino acid positions under which the B95-8 prototype amino acid and nucleotide sequence are listed. Different patterns are indicated in the left column. Only sequences that differed from B95-8 are shown. The lowercase letters indicate the nucleotide, and the amino acids are represented by capital letters. Asterisks $\left(^{*}\right)$ indicate the deletion of an amino acid. GD2 is the nucleotide 49551-49566 deletion.

Table 1. Subtype distributions of sequence variations in NPC samples and TWs from Southern China

\begin{tabular}{lcll}
\hline & NPCs $(\mathrm{n}=32), \%$ & TWs $(\mathrm{n}=39), \%$ & Total, $\mathrm{n}$ \\
\hline E2-A & $71.9(23 / 32)$ & $38.5(15 / 39)$ & 38 \\
E2-C & $28.1(9 / 32)$ & $35.9(14 / 39)$ & 23 \\
B95-8-like & $0(0 / 32)$ & $25.6(10 / 39)$ & 10 \\
\hline
\end{tabular}

at 3 residues, including AA378 (Ger $\rightarrow$ Tyr), 411 (Val $\rightarrow$ Ile) and 451 (Pro $\rightarrow$ His).

The least common subtype, B95-8-like (represented by TA56), only had 1 mutation at residue $370(\mathrm{cct} \rightarrow \mathrm{cca})$.

\section{Sequence Variant Subtype Distribution in NPCs and TWs}

The frequency of EBNA-2 subtypes in the NPC samples and TWs of healthy donors is summarized in table 1. E2-A was the predominant subtype in the tested speci-

EBNA-2 Polymorphic Patterns in NPC in Southern China mens $(38 / 71,52.1 \%)$ of the total samples, including $22 / 32$ (71.9\%) NPCs and 15/39 (38.5\%) TWs. E2-C was found in $32.4 \%(23 / 71)$ of the specimens, including $9 / 32(28.1 \%)$ NPCs and 14/39 (35.9\%) TWs (table 1). The B95-8-like subtype was only identified in a quarter of the TWs (10/39; $25.6 \%)$.

The distribution of the EBNA-2 subtypes between the NPCs and TWs was significantly different $(\mathrm{p}<0.01)$. The proportion of E2-A in NPCs $(71.9 \%$; 22/32) was significantly higher than in TWs $(38.5 \% ; 15 / 39)$, whilst the proportion of the B95-8-like subtype in TWs $(25.6 \%$; 10/39) was significantly higher than in NPCs $(0 \% ; 0 / 32)$.

\section{Discussion}

In this study, 32 NPC biopsies and 39 TWs of healthy donors in Southern China were successfully sequenced for the EBNA-2 gene. The DNA extraction methods used for the NPC samples and the TWs were both standard procedures and had no implication on the results. To the best of our knowledge, this is the first analysis of EBNA-2 sequence variations in Southern China, an endemic area of NPC. Based on the phylogenetic tree and the variation patterns of EBNA-2, all isolates could be subdivided into three subtypes, namely E2-A, E2-C and B95-8-like.

E2-A (53.5\%; 38/71) was the predominant subtype in Southern China. The common sequence changes for this subtype were 370 (cct $\rightarrow$ cca), 417 (acg $\rightarrow$ aca), 470 (tca $\rightarrow$ tct), 476 (Glu $\rightarrow$ Gly/Trp) and 486 (Ile $\rightarrow$ Thr). These mutations were also identified in our previous studies on NPC in Northern China, in the study by Kwok et al. [21] on NPC in Hong Kong (fig. 3), and in the study by Walling et al. [22], with the exception of 486 (Ile $\rightarrow$ Thr).

Subtype E2-C (32.4\%; 23/71) was the second most common subtype in Southern China. The common sequence changes for this subtype were AA370 (cct $\rightarrow \mathrm{cca}$ ) and two AA deletions (AA357 and 358). Similar results were also detected in our previous studies on NPC in Northern China [18] and in the study by Kwok et al. [21]. The AA370 (cct $\rightarrow$ cca) mutation was identified in the study by Walling et al. [22], but not the AA357 and 358 deletions. The consensus sequence of this subtype was identical to that of GD1, which is an EBV strain that was isolated from an NPC patient in Southern China [23]. The B95-8-like subtype (14.1\%; 10/71) was the least common subtype in Southern China, with only 1 mutation at 370 (cct $\rightarrow$ cca).

Additionally, the synonymous variant at residue 370 $(\mathrm{cct} \rightarrow \mathrm{cca})$ was detected in nearly all the isolates of this 
Fig. 4. EBNA-2 sequence variations in NPCs and TWs in Northern China. The numbers across the top correspond to the amino acid positions under which the B958 prototype amino acid and nucleotide sequence are listed. Different patterns are indicated in the left column while the specimens showing sequences identical to each other are represented by a single isolate in the second column. The numbers in parentheses indicate the number of identical sequences from NPCs and TWs, respectively. Only sequences that differed from B95-8 are shown. The lowercase letters indicate the nucleotide, and the amino acids are represented by capital letters. The consensus mutations of each pattern are shaded. Asterisks $\left(^{*}\right)$ indicate the deletion of an amino acid. T represents the TW samples, and $\mathrm{N}$ represents the NPC tissues.

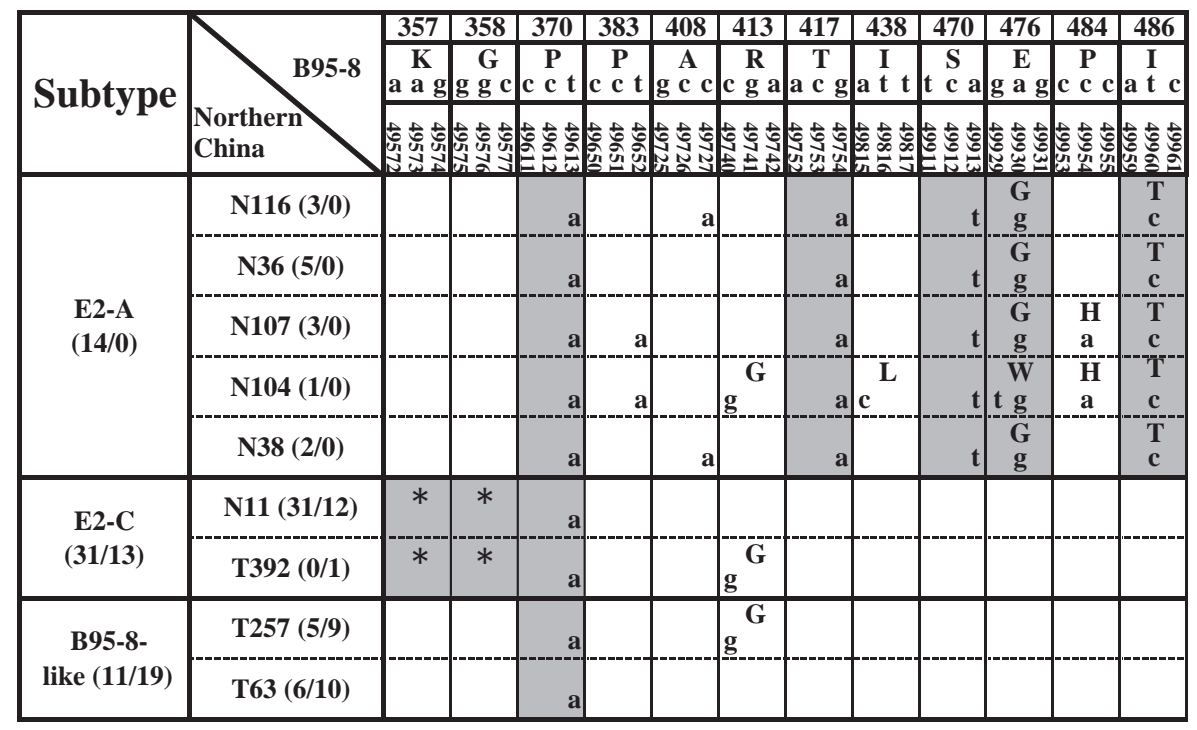

Table 2. Distribution of variant subtypes between the NPC samples from Southern and Northern China

\begin{tabular}{llll}
\hline & $\begin{array}{l}\text { NPCs in Northern } \\
\text { China }(\mathrm{n}=56), \%\end{array}$ & $\begin{array}{l}\text { NPCs in Southern } \\
\text { China }(\mathrm{n}=32), \%\end{array}$ & $\chi^{2}$ \\
\hline E2-A & $25.0(14 / 56)$ & $71.9(23 / 32)$ & $\mathrm{p}<0.01$ \\
E2-C & $55.4(31 / 56)$ & $28.1(9 / 32)$ & $\mathrm{p}<0.05$ \\
B95-8-like & $19.6(11 / 56)$ & $0(0 / 32)$ & $\mathrm{p}<0.01$
\end{tabular}

study $(97.2 \% ; 69 / 71)$, and was also identified in all of the NPC, gastric carcinoma and healthy adult TW samples in our previous study [18]. This variant was also reported in 6 human immunodeficiency virus-infected patients and the NPC samples from Hong Kong or Guangzhou [22], in the work of Kwok et al. [21] (fig. 3) and in oral hairy leukoplakia samples from the USA [22, 24], indicating that 370 (cct $\rightarrow$ cca) might be a common allele around the world.

Whether a particular EBV strain contributes to the development of specific EBV-associated malignancies is still debatable. In our previous studies of EBNA-2 gene polymorphisms in NPC, gastric carcinoma and TWs from Northern China, E2-A was detected only in NPC, which suggests the strain with specific mutations plays an important role in the pathogenesis of NPC (because the sequence regions were not the same, we redivided the Northern Chinese results according to the variation patterns of Southern China; fig. 4; table 3) [18]. Similarly, in this study we found that the E2-A subtype was signifi-
Table 3. Subtype distributions of sequence variations in NPC samples and TWs from Northern China

\begin{tabular}{llll}
\hline & $\begin{array}{l}\text { NPCs } \\
(\mathrm{n}=56), \%\end{array}$ & $\begin{array}{l}\text { TWs } \\
(\mathrm{n}=32), \%\end{array}$ & Total, $\mathrm{n}$ \\
\hline E2-A & $25.0(14 / 56)$ & $0(0 / 32)$ & 14 \\
E2-C & $55.4(31 / 56)$ & $40.6(13 / 32)$ & 44 \\
B95-8-like & $19.6(11 / 56)$ & $59.4(19 / 32)$ & 30 \\
\hline
\end{tabular}

cantly more common in NPCs than in TWs $(\mathrm{p}<0.01$; table 1), and it was also more frequent than in the samples from Northern China ( $\mathrm{p}<0.01$; table 2). E2-A was also identified as the predominant subtype in the Hong Kong NPC study conducted by Kwok et al. [21] (fig. 3). As an endemic NPC region, the high frequency of E2-A in Southern China suggests that the E2-A subtype may play an important role in the pathogenesis of NPC and that EBNA-2 gene variations are tumor-specific polymorphisms. However, genetic variations in the small subsets of the genes investigated were not sufficient to assess the geographical distribution of EBV variants and their precise associations with diseases. Whole genome sequences and a genome-wide comparison of the variations found in EBV genomes isolated from NPC and normal subjects are needed to determine the role of EBV genomic variations in the pathogenesis of NPC, which will be the focus of our future studies.

Other factors may influence the occurrence of cancers, such as host genetics and the environment. For example, 
$5 \mathrm{p} 13.1$ was identified as a subset of hereditary risk for NPC [25], and 3p21 may play a critical role in the tumorigenesis of familial NPC [26]. Salted fish containing volatile nitrosamines, cigarette smoking and the consumption of alcohol are environmental factors associated with the development of NPC [27]. DNA methylation is known to contribute to interindividual phenotypic variations and has recently been linked to the pathogenesis of cancer and complex disease phenotypes [28, 29].

EBNA-2 contains three domains critical for its transcription regulation function: the self-association domain (122-232 aa), trans-activation domain (TAD; 431$487 \mathrm{aa}$ ) and nuclear localization signals (NLS; 244-378 aa and 466-483 aa) [30, 31]. TAD (431-487 aa) and NLS (244-378 aa and 466-483 aa) were sequenced in this study.

TAD is a strong transcriptional activator, particularly in B lymphocytes, and is essential for the EBNA-2 activation of cells and viral genes [32]. Additionally, it has been previously shown that the amino acid composition of TAD is similar to that of a number of human and viral TADs, including the human tumor suppressor protein p53 and the herpes simplex viral protein 16 [33]. Meanwhile, it has been reported that TAD binds to the pleckstrin homology domain of the Tfb1/p62 subunit of TFIIH and determines the three-dimensional structure of a complex between EBNA-2 and Tfb1/p62 [34]. The AA476 (Glu $\rightarrow$ Gly/Trp) and 486 (Ile $\rightarrow$ Thr) mutations in this study were detected in this domain.

AA335-362 in the NLS domain is a protein-protein and protein-nucleic acid interaction domain, important for efficient cell growth transformation, and a downregulator of the LMP1 promoter [32]. Meanwhile, AA357363 has been proven to be the protein kinase $C$ phosphorylation site, which could reduce the formation of the EBNA-2/CBF1 complex [35]. The AA357/358 deletions and the AA476 (Glu $\rightarrow$ Gly/Trp) mutation in this important region are likely to affect the function of EBNA-2, which warrants further functional studies.

Considering the shortcomings of this work, in future studies direct comparison of TWs and NPC tissue from the same population and on the same patients should be included. This may be difficult but would be very useful in indicating the tissue specificity of the genotypic changes.

In conclusion, subtype E2-A was the predominant subtype in Southern China. The distribution of EBNA-2 subtypes between NPCs and TWs was significantly different $(\mathrm{p}<0.01)$. The E2-A subtype is significantly more frequent in NPCs than in TWs, and is also more common than in Northern China, which suggests that the E2-A subtype may play an important role in the pathogenesis of NPC and that EBNA-2 gene variations are tumor-specific polymorphisms.

\section{Acknowledgements}

This work was supported by the Specialized Research Fund for the Doctoral Program of Higher Education, grant No.: 20133706110001; the Natural Science Foundation of Shandong Province, grant No.: ZR2015040070, and Science and Technology of Qingdao City, China, grant No.: 13-1-4-126-jch.

\section{References}

1 Tsao SW, Tsang CM, To KF, Lo KW: The role of Epstein-Barr virus in epithelial malignancies. J Pathol 2015;235:323-333.

2 Vockerodt M, Yap LF, Shannon-Lowe C, Curley H, Wei W, Vrzalikova K, Murray PG: The Epstein-Barr virus and the pathogenesis of lymphoma. J Pathol 2015;235:312-322.

3 Niller $\mathrm{HH}$, Wolf H, Minarovits J: Regulation and dysregulation of Epstein-Barr virus latency: implications for the development of autoimmune diseases. Autoimmunity 2008;41: 298-328.

4 Bray F, Haugen M, Moger TA, Tretli S, Aalen OO, Grotmol T: Age-incidence curves of nasopharyngeal carcinoma worldwide: bimodality in low-risk populations and aetiologic implications. Cancer Epidemiol Biomarkers Prev 2008;17:2356-2365.
5 Chang ET, Adami HO: The enigmatic epidemiology of nasopharyngeal carcinoma. Cancer Epidemiol Biomarkers Prev 2006;15: 1765-1777.

6 Hsu JL, Glaser SL: Epstein-Barr virus-associated malignancies: epidemiologic patterns and etiologic implications. Crit Rev Oncol Hematol 2000;34:27-53.

7 Dawson CW, Eliopoulos AG, Blake SM, Barker R, Young LS: Identification of functional differences between prototype Epstein-Barr virus-encoded $\operatorname{lmp} 1$ and a nasopharyngeal carcinoma-derived lmp1 in human epithelial cells. Virology 2000;272:204-217.

8 Fielding CA, Sandvej K, Mehl A, Brennan P, Jones M, Rowe M: Epstein-Barr virus lmp-1 natural sequence variants differ in their potential to activate cellular signaling pathways. J Virol 2001;75:9129-9141.
9 Gutierrez MI, Raj A, Spangler G, Sharma A, Hussain A, Judde JG, Tsao SW, Yuen PW, Joab I, Magrath IT, Bhatia K: Sequence variations in EBNA-1 may dictate restriction of tissue distribution of Epstein-Barr virus in normal and tumour cells. J Gen Virol 1997;78: 1663-1670.

10 Gutierrez MI, Spangler G, Kingma D, Raffeld M, Guerrero I, Misad O, Jaffe ES, Magrath IT, Bhatia K: Epstein-Barr virus in nasal lymphomas contains multiple ongoing mutations in the EBNA-1 gene. Blood 1998;92:600-606.

11 Mai SJ, Ooka T, Li DJ, Zeng MS, Jiang RC, Yu XJ, Zhang RH, Chen SP, Zeng YX: Functional advantage of NPC-related V-val subtype of Epstein-Barr virus nuclear antigen 1 compared with prototype in epithelial cell line. Oncol Rep 2007;17:141-146. 
12 Murray PG, Young LS: The role of the Epstein-Barr virus in human disease. Front Biosci 2002;7:d519-d540.

13 Radkov SA, Bain M, Farrell PJ, West M, Rowe M, Allday MJ: Epstein-Barr virus EBNA3C represses $\mathrm{Cp}$, the major promoter for EBNA expression, but has no effect on the promoter of the cell gene CD21. J Virol 1997;71:85528562.

14 Kaiser C, Laux G, Eick D, Jochner N, Bornkamm GW, Kempkes B: The proto-oncogene c-myc is a direct target gene of Epstein-Barr virus nuclear antigen 2. J Virol 1999;73:4481-4484.

15 Weiss LM, Movahed LA: In situ demonstration of Epstein-Barr viral genomes in viralassociated B cell lymphoproliferations. Am J Pathol 1989;134:651-659.

16 Hsieh JJ, Henkel T, Salmon P, Robey E, Peterson MG, Hayward SD: Truncated mammalian Notch1 activates CBF1/RBPJk-repressed genes by a mechanism resembling that of Epstein-Barr virus EBNA2. Mol Cell Biol 1996; 16:952-959.

17 Henkel T, Ling PD, Hayward SD, Peterson MG: Mediation of Epstein-Barr virus EBNA2 transactivation by recombination signalbinding protein J kappa. Science 1994;265: 92-95.

18 Wang X, Wang Y, Wu G, Chao Y, Sun Z, Luo B: Sequence analysis of Epstein-Barr virus EBNA-2 gene coding amino acid 148-487 in nasopharyngeal and gastric carcinomas. Virol J 2012;9:49.

19 Sugiura M, Imai S, Tokunaga M, Koizumi S, Uchizawa M, Okamoto K, Osato T: Transcriptional analysis of Epstein-Barr virus gene expression in EBV-positive gastric carcino- ma: unique viral latency in the tumour cells. Br J Cancer 1996;74:625-631.

20 Ikuta K, Satoh Y, Hoshikawa Y, Sairenji T: Detection of Epstein-Barr virus in salivas and throat washings in healthy adults and children. Microbes Infect 2000;2:115-120.

21 Kwok H, Wu CW, Palser AL, Kellam P, Sham PC, Kwong DL, Chiang AK: Genomic diversity of Epstein-Barr virus genomes isolated from primary nasopharyngeal carcinoma biopsy samples. J Virol 2014;88:10662-10672.

22 Walling DM, Perkins AG, Webster-Cyriaque J, Resnick L, Raab-Traub N: The Epstein-Barr virus EBNA-2 gene in oral hairy leukoplakia: strain variation, genetic recombination, and transcriptional expression. J Virol 1994;68: 7918-7926.

23 Zeng MS, Li DJ, Liu QL, Song LB, Li MZ, Zhang RH, Yu XJ, Wang HM, Ernberg I, Zeng YX: Genomic sequence analysis of EpsteinBarr virus strain GD1 from a nasopharyngeal carcinoma patient. J Virol 2005;79:1532315330.

24 Walling DM, Raab-Traub N: Epstein-Barr virus intrastrain recombination in oral hairy leukoplakia. J Virol 1994;68:7909-7917.

$25 \mathrm{Hu}$ LF, Qiu QH, Fu SM, Sun D, Magnusson $\mathrm{K}, \mathrm{He} \mathrm{B}$, Lindblom A, Ernberg I: A genomewide scan suggests a susceptibility locus on 5 p13 for nasopharyngeal carcinoma. Eur J Hum Genet 2008;16:343-349.

26 Xiong W, Zeng ZY, Xia JH, Xia K, Shen SR, Li $\mathrm{XL}$, et al: A susceptibility locus at chromosome 3 p21 linked to familial nasopharyngeal carcinoma. Cancer Res 2004;64:1972-1974.

27 Guo X, Johnson RC, Deng H, Liao J, Guan L, Nelson GW, Tang M, Zheng Y, de The G, O’Brien SJ, Winkler CA, Zeng Y: Evaluation of nonviral risk factors for nasopharyngeal carcinoma in a high-risk population of Southern China. Int J Cancer 2009;124:2942-2947.

28 Feinberg AP: Phenotypic plasticity and the epigenetics of human disease. Nature 2007; 447:433-440.

29 Mill J, Tang T, Kaminsky Z, Khare T, Yazdanpanah S, Bouchard L, Jia P, Assadzadeh A, Flanagan J, Schumacher A, Wang SC, Petronis A: Epigenomic profiling reveals DNAmethylation changes associated with major psychosis. Am J Hum Genet 2008;82:696711.

30 Cohen JI, Wang F, Kieff E: Epstein-Barr virus nuclear protein 2 mutations define essential domains for transformation and transactivation. J Virol 1991;65:2545-2554.

31 Cohen JI, Kieff E: An Epstein-Barr virus nuclear protein 2 domain essential for transformation is a direct transcriptional activator. J Virol 1991;65:5880-5885.

32 Peng CW, Zhao B, Kieff E: Four EBNA2 domains are important for EBNALP coactivation. J Virol 2004;78:11439-11442.

33 Cohen JI: A region of herpes simplex virus VP16 can substitute for a transforming domain of Epstein-Barr virus nuclear protein 2. Proc Natl Acad Sci USA 1992;89:8030-8034.

34 Chabot PR, Raiola L, Lussier-Price M, Morse T, Arseneault G, Archambault J, Omichinski JG: Structural and functional characterization of a complex between the acidic transactivation domain of EBNA2 and the Tfb1/p62 subunit of TFIIH. PLoS Pathog 2014; 10:e1004042.

35 Ling PD, Hayward SD: Contribution of conserved amino acids in mediating the interaction between EBNA2 and CBF1/RBPJk. J Virol 1995;69:1944-1950. 